\title{
Skills for employability:Identification of the Soft Skills required in engineering education
}

\author{
CHAIBATE Hind*, hind.chaibate.ensem@ gmail.com \\ BAKKALI Soumia*, s.bakkali@hotmail.com \\ AJANA Souad*, souadboutaleb@gmail.com \\ AIT HADDOUCHANE Zineb*, aithaddouchane.zineb@ gmail.com \\ ZERGOUT Imane*, zergout.imane@ gmail.com \\ *Team of Research in Engineering Education \\ Engineering Research Laboratory \\ ENSEM- Hassan II University of Casablanca, Morocco
}

\section{Introduction}

In the age of globalization, the industrial sector is characterized by a strong competition, which makes it more and more demanding in terms of the skills required for professional insertion[1]. Moroccan Development Strategy aims to promote growth, high-quality jobs and living through sustainable and competitive integrated solutions. Smart city is a development vision to improve quality of life by using information and communicationstechnologies (ICT) to achieve sustainability and meet citizens' needs [2].Engineering schools have to meet the challenge to train engineers with a high level of technical as well as managerial skills by adoptingsmart city technologies. Indeed, the managerial skills play a key role in the educationof innovativeengineers who are able to contribute effectively to the development of smart city and face today's strategies.

We have previously conducted a study in view of collecting data from professionals in companies operating in different sectors in Morocco. The findings show that Moroccan engineers' skills are still unsatisfactory when compared to the requirements of the job market. We have also identified a number of weaknesses of recruited engineers, namely incommunication, autonomy, decision making, efficiency, management of priorities, teamwork, stress management, self-confidence, creativity, initiative, and negotiation [3].

The purpose of this study is to identify the necessary soft skills that enable engineers to engage in the successful implementation of smart city. These skills refer to personal, managerial, ethical, professional, digital and technological skills. In the first place, we have identified the soft skills required by accreditation bodies in some developed countries like the United States, Europe, Korea, and Australia, in which these skills are subsequently correlated with the CDIO syllabus. In the second place, through this study, we've attempted to highlight a set of soft skills which we compared with those developed in the Moroccan engineering education programs in order to detect the shortcomings of the latter.

\section{Soft skills according to engineering accreditation bodies}

Accreditation is an important factor of improvement of the quality of the engineering education around the world. In order to be accredited, the engineering program has to meet a number of criteria defined by the accreditation bodies.

In our work, we selected a sample which refers to American, European, Asian and Australian accreditation bodies that we have briefly described in table 1 . 


\begin{tabular}{|l|l|}
\hline Accreditation bodies & \multicolumn{1}{|c|}{ Description } \\
\hline ABET & $\begin{array}{l}\text { ABET (The Accreditation Board for Engineering and Technology), is an } \\
\text { organization that accredits engineering programs, programs of the applied } \\
\text { science, of computer science, and of technology in the United States[4]. }\end{array}$ \\
\hline ENAEE & $\begin{array}{l}\text { ENAEE (European Network for Engineering Accreditation), is a European } \\
\text { association that was founded thanks to the Bologna Process which aims at } \\
\text { creating a common European Higher Education Area (EHEA). ENAEE enables } \\
\text { accreditation bodies to deliver EUR-ACE label (EURopean- ACcredited } \\
\text { Engineer) to the accredited engineering programs[5]. }\end{array}$ \\
\hline ABEEK & $\begin{array}{l}\text { ABEEK (Accreditation Board for Engineering Education of Korea), is an } \\
\text { accreditation body aiming at improving the quality of the Korean engineering } \\
\text { educationthrough accreditation of engineering programs[6]. }\end{array}$ \\
\hline EA & $\begin{array}{l}\text { EA (Engineers Australia) is an Australian accreditation body that ensures the } \\
\text { quality of the engineering trainingthrough accreditation of the engineering } \\
\text { programs[7]. }\end{array}$ \\
\hline
\end{tabular}

Table 1: Engineering accreditation bodies

In this work we are particularly interested in identifying the soft skills required by the accreditation bodiesabove mentioned in table 1.For this purpose, we've conducted an extensive literature review based on recent articles $[4,5,6,11,8,9,10,13]$ and recently revised accreditation textbooks $[7,12,14,15]$. This study has led to a list of the following soft skills:

- Practice engineeringwhile respecting economic, environmental (sustainability), social, political and ethical constraints

- Have a sense of ethical and professional responsibility

- Keep up to date on the development of knowledge in engineering

- Have knowledge of contemporary issues

- Be able to use information and communication technologies in engineering practice

- Apply system thinking approaches to conduct and manage engineering projects

- Identify, formulate, and solve engineering problems

- Be able to work within multidisciplinary teams

- Use the techniques and modern engineering tools necessary for the engineering practice

- Communicate effectively

- Have a creative, innovative and proactive spirit

- Have a sense of leadership and entrepreneurship

- Develop critical thinking skills

- Be able to engage in lifelong learning

This study has enabled us to construct a global vision of engineering soft skills needed to be effective in an international professional level. We note that the identified soft skills don't describe their components. For this reason, we have recourse to an engineering education syllabus which gives a detailed description of skills.

\section{Soft skills according to the CDIO syllabus}

CDIO stands for Conceive-Design-Implement-Operate, the CDIO initiativewas initiated at the Massachusetts Institute of Technology (MIT) in USAin collaboration with three Swedish universities Chalmers University of Technologyin Göteborg, Linköping University in Stockholm and the Royal Institute of Technology in Linköping.It became an international collaboration, with more than a hundreduniversities around the world adopting the same frameworkapproach. This initiative is an innovative framework set in the context of Conceiving - Designing - Implementing — Operating (CDIO)for educating the next 
generation of engineers. The CDIO Syllabus was developed through focus groups comprised of engineering institutes, industry representatives and the government. Itcontains a set ofskills and attitudes that modern engineering students should possess. These learning outcomes are classified into fourcategoriesdetailed in figure $1[16,17,18,19]$.

Disciplinary knowledge and engineering fundamentals

$>$ Personal and professional skills and attributes

$>$ Interpersonalskills: teamwork and communication

$>$ Skills related to engineering practice: conceive, design, implement, operate

In the present study, in order to choose the adequate syllabus, we were interested intwo criteria:

-Criterion 1: The chosen syllabus must contain general engineering skills regardless of any engineering field.

-Criterion2: The chosen syllabus must contain and detail all the soft skills identified from the accreditation bodies in the first part.

The CDIO syllabus meets the first criterion (criterion 1) because it represents a model of engineering program applicable toall the engineering fields.

For the purposes of determining the extent to which the CDIO syllabus meets the second criterion (criterion 2), the soft skills identified from the accreditation bodies in the first partwere correlated with the skills in the CDIO syllabus. 


\section{Disciplinary knowledge and engineering} fundamentals

1.1 Basic knowledge of mathematics and other sciences

1.2 Basic knowledge of engineering fundamentals 1.3 Advanced knowledge of engineering fundamentals, techniques, and tools
2 Personal and professional skills and attributes

2.1 Engineering Reasoning and Problem Solving

2.2 Experimentation and knowledge discovery

2.3 system thinking

2.4 Attitude, thinking, and cognition

2.5 Ethics, impartiality, and other forms of responsibility
3 Interpersonal skills: teamwork and communication

3.1 Teamwork

3.2 Communication

3.3 Communication in foreign languages
4 Skills related to engineering practice: conceive, design, implemente, operate

4.1 External and societal context

4.2 Entreprise and business context

4.3 Conceiving, system engineering and management

4.4 Designing

4.5 Implementing

4.6 Operating

4.7 Leading Engineering Endeavors

4.8 Engineering entrepreneurship

Figure 1: CDIO syllabus structure

4. Correlatingthe engineering accreditation bodies skills with the CDIO syllabus After identifying the soft skills required by the engineering accreditation bodies, these skills were correlated with the CDIO syllabus as shown in table 2. 


\begin{tabular}{|c|c|c|c|c|c|c|c|c|c|c|c|c|c|c|c|c|c|c|c|c|}
\hline & & \multicolumn{19}{|c|}{ CDIO syllabus } \\
\hline & & 1.1 & 1.2 & 1.3 & 2.1 & 2.2 & 2.3 & 2.4 & 2.5 & 3.1 & 3.2 & 3.3 & 4.1 & 4.2 & 4.3 & 4.4 & 4.5 & 4.6 & 4.7 & 4.8 \\
\hline \multirow{14}{*}{ 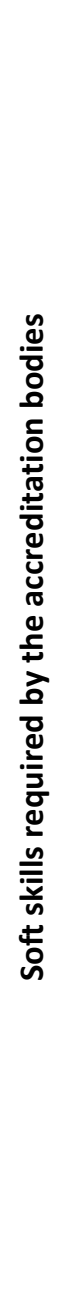 } & $\begin{array}{c}\text { Practice engineering while respecting } \\
\text { economic, environmental (durability), } \\
\text { social, political and ethical } \\
\text { constraints }\end{array}$ & & & & & & & & & & & & $\mathrm{x}$ & $\mathrm{x}$ & & & & & & \\
\hline & $\begin{array}{l}\text { Have a sense of ethical and } \\
\text { professional responsibility }\end{array}$ & & & & & & & & $\mathrm{x}$ & & & & & & & & & & & \\
\hline & $\begin{array}{l}\text { keep up to date on the development } \\
\text { of knowledge in engineering }\end{array}$ & & & & & $\mathrm{x}$ & & & & & & & & & & & & & & \\
\hline & $\begin{array}{c}\text { Have a knowledge of contemporary } \\
\text { issues }\end{array}$ & $x$ & & & & & & & & & & & $\mathrm{x}$ & & & & & & & \\
\hline & $\begin{array}{c}\text { Be able to use information and } \\
\text { communication technologies in } \\
\text { engineering practice }\end{array}$ & & & & & & & & & & $\mathrm{x}$ & & & & & & & & & \\
\hline & $\begin{array}{l}\text { Apply system thinking approaches to } \\
\text { conduct and manage engineering } \\
\text { projects }\end{array}$ & & & & & & $\mathrm{x}$ & & & & & & & & & & & & & \\
\hline & $\begin{array}{l}\text { Identify, formulate, and solve } \\
\text { engineering problems }\end{array}$ & & & & $\mathrm{x}$ & & & & & & & & & & & & & & & \\
\hline & $\begin{array}{l}\text { Be able to work within } \\
\text { multidisciplinary teams }\end{array}$ & & & & & & & & & $X$ & & & & & & & & & & \\
\hline & $\begin{array}{c}\text { Use the techniques and modern } \\
\text { engineering tools necessary for the } \\
\text { engineering practice }\end{array}$ & & & $\mathrm{x}$ & & & & & & & & & & & & & & & & \\
\hline & Communicate effectively & & & & & & & & & & $\mathrm{x}$ & & & & & & & & & \\
\hline & $\begin{array}{l}\text { Be creative, innovative and } \\
\text { proactive }\end{array}$ & & & & & & & $\mathrm{x}$ & & & & & & & $\mathrm{x}$ & & & & $x$ & \\
\hline & $\begin{array}{l}\text { Have a sense of leadership and } \\
\text { entrepreneurship }\end{array}$ & & & & & & & $\mathrm{x}$ & & & & & & & & & & & & $\mathrm{x}$ \\
\hline & Develop critical thinking skills & & & & & & & $\mathrm{x}$ & & & & & & & & & & & $\mathrm{x}$ & \\
\hline & Be able to engage in lifelong learning & & & & & & & $\mathrm{x}$ & & & & & & & & & & & & \\
\hline
\end{tabular}

Tableau 2: Accreditation bodies requirements correlated with the CDIO syllabus 
The major advantage of the CDIO Syllabus is that it is more detailed, containing all the skills identified at the beginning of the study from the accreditation bodies. These skills can be included at least in one of the components of the CDIO syllabus. For example, the skill calling for "being creative, innovative and proactive"is integrated in the three axes of the CDIO syllabus (2.4 Attitude, thinking, and cognition, 4.3 conceiving system engineering and management and 4.7 Leading Engineering Endeavors).

According to the results of the correlation,it can be confirmed that the CDIO syllabus fully meets the criterion 2 defined in section 3.For this reason, we will focus on this syllabus to give a more encompassing view of the engineering soft skills.

\section{Soft skills identification and distribution}

Soft skills are a combination of personal and interpersonal skills and abilities that improve the engineer's employability. These skills are present in any engineering framework[20].We've conducted an extensive literature review that has enabled us toorganize soft skills into five categories:

Entrepreneurship skills:The entrepreneurship skills are defined as the abilities to successfully establish a new business in order to make a profit.These skills incite engineers to undertakethe risk of establishing a new business seeking profit opportunities by satisfying unsatisfied needs[21].

Personal and interpersonal skills:thepersonal skillsrevealed in the attitudes and abilities used by a person to perform an activity. They include, for example,initiative, responsibility and adaptability. Interpersonal skills refer to the set of abilities needed by a person to interact with others properly, such ascommunication and team working[22].

Managerial skills: These skills include the ability to plan a project and manage the project resources (time, staff, budget...)[23].

Ethical and professional skills: These skills describe professional conduct and the ability topractice engineering while respecting economic, environmental (sustainability), social, political and ethical constraints[23].

Digital and technological skills: In the digital era,the application of technology in the engineering practice is becoming a necessity. Engineers must be able to use information and communication technologies in order to perform their work and ensure employability[24].

Engineers must have all the skills and abilities that enable them to be involved in promoting economic social and environmental development. In this way, Smart City is expected to be a key way to combine sustainability with continued economic growth. This means that cities will resolve many global challenges related to environmental (climate change, pollution, resources management), economic (infrastructures deficit, lack of competitiveness, access to technology) and social issues (poverty, job crisis, inequality)in order to generate new services and facilities across all areas of the city by using advanced technologies. Smart city requires collaboration between Citizens, governments and other city organizations. It highly depends on stakeholder's awareness and perceptions of the usefulness of this initiative[2]. Smart solutions can be implemented by leaders, academics and industrial experts. Engineer as a future decision maker, should be able to successfully lead this radical transformation and generate innovative improvement. For this reason, we have identified in our study the principal skills that enable engineers to make a very significant contribution to community development.In table 3, we have divided the soft skills in the CDIO syllabus into the five categories presented above (entrepreneurship skills, personal and interpersonal skills, managerial skills, ethical and professional skills, digital and technological skills). For example, digital and technological skills can help engineers make full use of emerging smart city technologies and develop digital creation skills such as design and programming skills. Ethical and professional skills are extremely important in reducing environmental impact 
and promoting sustainability, ethics and social values. Smart city cannot achieve its objectives without leaders with strong personal, interpersonal and managerial skills. Building skills is one mission that nations must place as one of the top priorities.

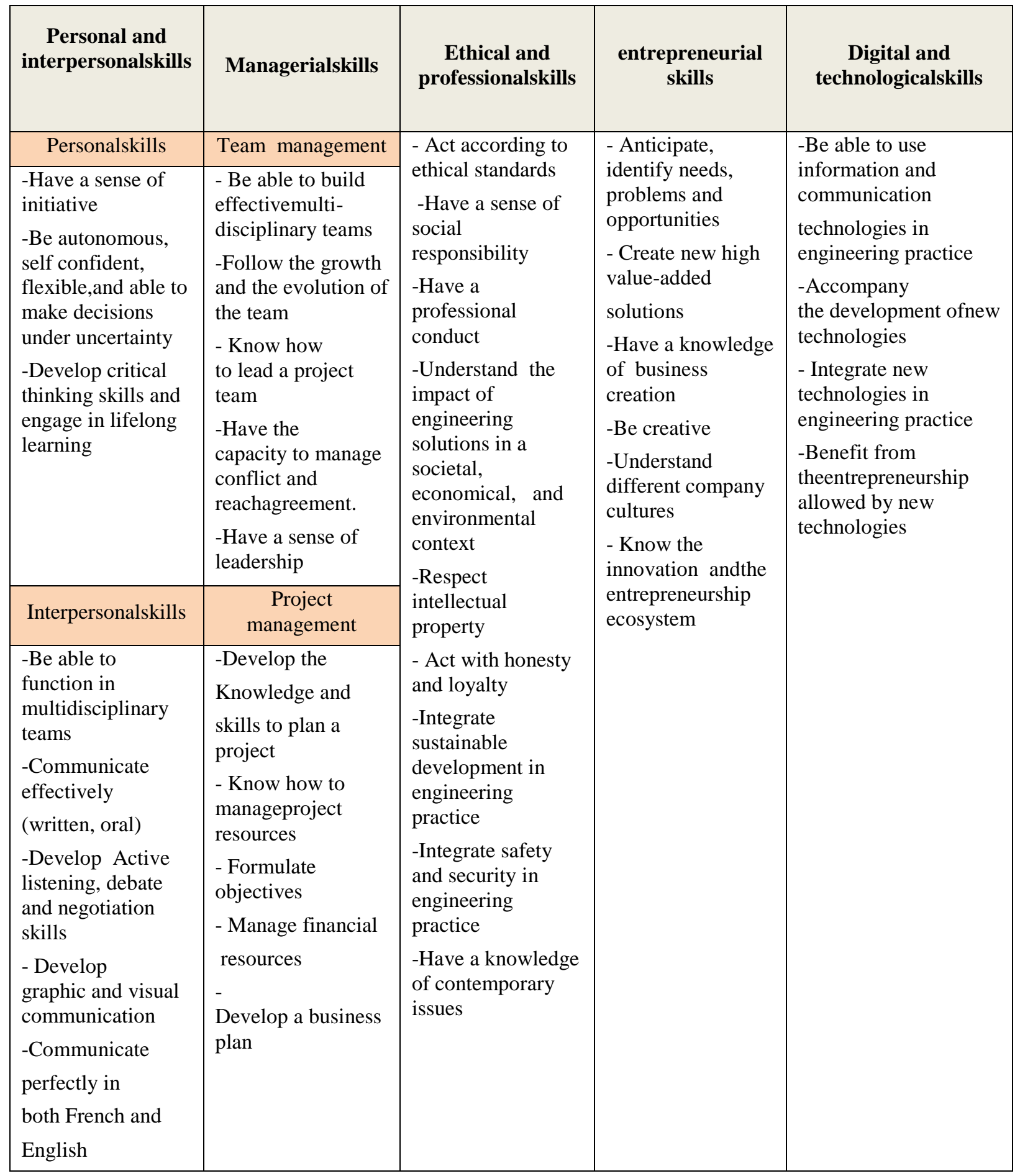

\section{Table 3: CDIO skills organisation}

This table identifies deeply the various soft skills described in the CDIO syllabus, whichwill enable us to facilitate the comparison between this syllabus and Moroccan engineering education syllabus. 


\section{Moroccan engineeringskills vs. the CDIO skills}

In Morocco, the engineering degree is mainly delivered by graduate schools of engineering, education takes usually 5 years of studies, comprising 2 years of preparatory classes that consist of the core courses (mathematics, physics, programming...) and 3 years of specialization within different fields of engineering. Some engineering schools include an integrated undergraduate cycle (preparatory cycle). The recruitment process is highly selective in all the engineering schools.

In order to identify the soft skills developed by Moroccan engineering programs, we have chosen two Moroccan engineering schools and studied their education programs. The first engineering school is with an integrated undergraduate cycle (preparatory cycle) and the second school is with a separated undergraduate cycle.

Table 4 describes the soft skills developed by management and communication modules along the five semesters of the engineering cycle $[25,26]$.

\begin{tabular}{|c|c|}
\hline Module & Objectives \\
\hline \multirow{9}{*}{ Management } & Get familiar with the business environment \\
\hline & Develop stress management skills \\
\hline & Develop self-coaching skills \\
\hline & Assert oneself socially or professionally \\
\hline & Learn about the role of the manager \\
\hline & Be effective, be able to plan work activities and set objectives \\
\hline & Develop time management skills \\
\hline & Be able to function on multidisciplinary teams and manage a project \\
\hline & Developleadership principles \\
\hline \multirow{4}{*}{$\begin{array}{l}\text { Language and } \\
\text { communication }\end{array}$} & $\begin{array}{l}\text { Communicateeffectively } \\
\text { (written, oral) }\end{array}$ \\
\hline & Develop technical and professional English \\
\hline & Developprofessionalwritingabilities \\
\hline & $\begin{array}{l}\text { Develop argumentation, negotiation and conflict management } \\
\text { techniques. }\end{array}$ \\
\hline
\end{tabular}

Tableau 4: Soft skills targeted by management and communication modules

The Moroccan engineering syllabusesaim at developing different types of skills and knowledge, such as stress management, leadership, communication, team work, time management, project management, argumentation, negotiation and conflict management.While, the comparison between these syllabuses and the CDIO syllabus reveals shortcomings related to the lack of ethical and digital skills, we also notice that the personal skills are not sufficiently detailed, which is also the same for project management and team management skills. This comparison results are described in figure 2. 
Soft skills developed in Moroccan engineering programs compared with those in the CDIO syllabus

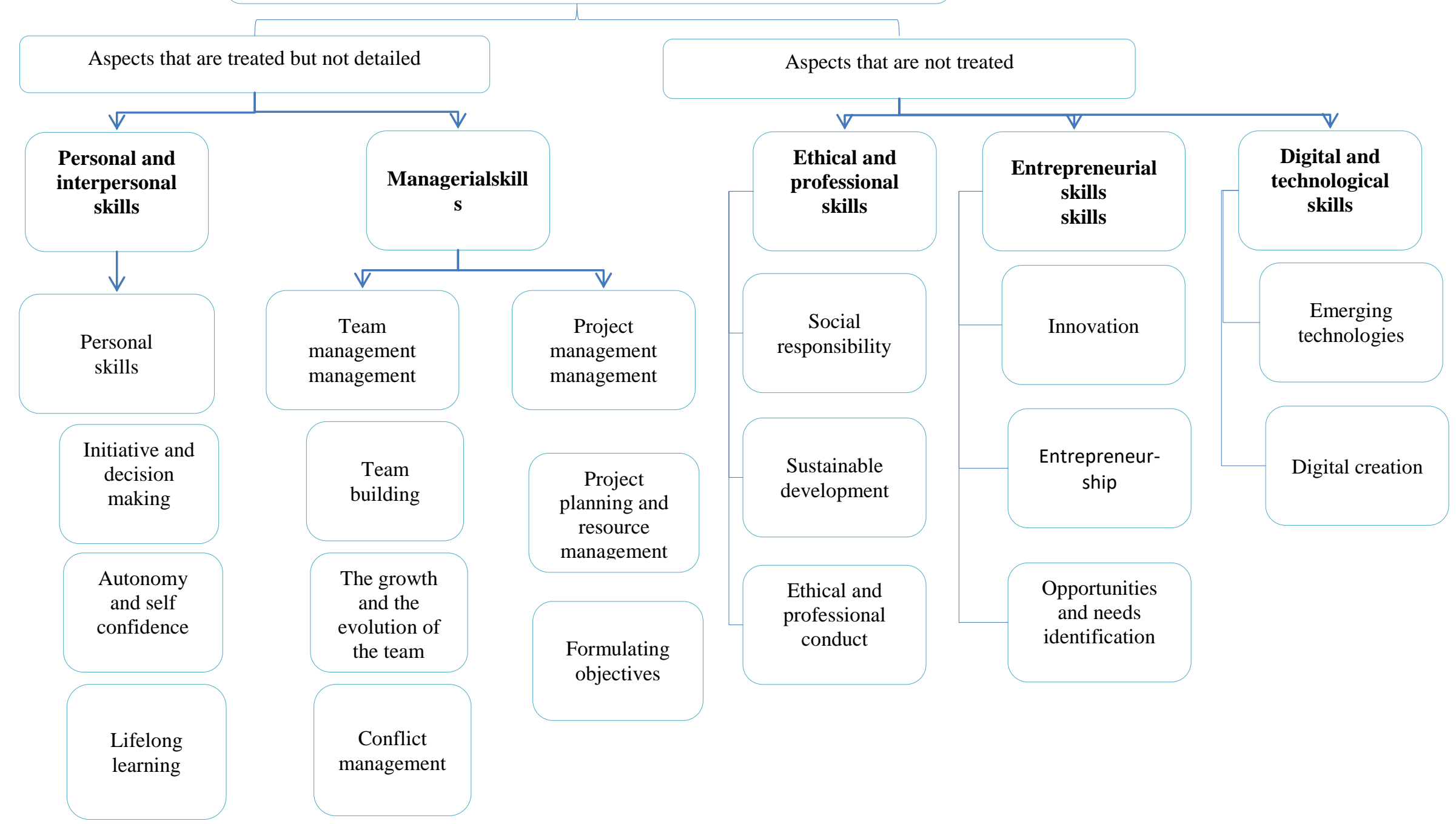

Figure 2: Comparison between Moroccan engineering skills and the CDIO skills 
Today Morocco knows an important strategic focus on strong infrastructures development for achieving smart cities. An example of a smart city initiative is the e-Madina initiative in Casablanca. It aims to transform Casablanca into a smart city by using new technologies to provide connectivity to its citizens and improve traffic flows[27].Moreover, His Majesty the King Mohammed the Sixth has chaired the ceremony to launch the project intended to build the new city of Mohammed the sixth Tangier Tech city. This new city is expected to be the first smart city in Morocco integrating ecology, habitability, industry, vitality and innovation.

In order to successfully enable clean technology and emerging information technology to become a reality, Citizens have to acquirea set ofskills and abilities to be actively involved in the development process such as entrepreneurship, innovation, ethics, professionalism, and technological thinking skills. Therefore, our current engineering educational processes should be oriented towards the challenges that our country is anticipated to face and deliver this kind of skills to Moroccan engineers.

\section{Conclusion}

Moroccan engineers must be educated in the context of globalization where the skills have an international dimension.Openness to the international level plays a determining competitive advantage. They should also acquire skills and abilities that enable them to participate effectively ineconomic, social and environmental growth.For this reason, we focused in this study on the identification of the soft skills required for theemployability of engineers worldwide.We started by identifying the soft skills required by the accreditation bodies in some developed countries, namely ABET (The Accreditation Board for Engineering and Technology), ENAEE (European Network for Accreditation of Engineering Education), ABEEK (Accreditation Board for Engineering Education of Korea and EA (Engineers Australia).Thereafter, we had recourse to the CDIO syllabus in order to describe the components of the soft skills identified from the accreditation bodies. We supportedthe choice of the CDIO syllabus by a correlation between it and the accreditation bodies of soft skills. Finally, we've conducted a comparison between the CDIO syllabus skills and the skills developed by the Moroccan engineering education programs in order to detect the skills that are not developed in the Moroccan engineering course.

The results of this study will enable us to suggest a list of soft skills that could complete skills already integrated in the Moroccan engineering education programs. We will validate the skills proposed through a questionnaire surveytargeting at industries operating in different sectors of activity in Morocco. Engineering schools have to apply innovative learning strategiesto develop this kind of skills. For this reason, we will conduct a study to determine the importance of adopting new technologies and pedagogical innovations for teaching and learning. 


\section{REFERENCES}

[1] Terfous N., Mondialisation et marché du travail dans les pays développés, Economie \& prévision, $\mathrm{N}^{\circ} 172$, pp. 117-124, 2006

[2] A. HAYAR, K. LAABOUDI, M. LAKHLIFI, C. MORENO, E. PRADEL-Lepage, A.VEYRET, Le Livre Blancde la ville intelligenteau Maroc, 2013

[3] CHAIBATE H., Ajana S., Ben Souda S.,Bakkali S., Faraj K., La formation d'ingénieurs au Maroc : Développement des compétences transversales «soft-skills» exigées par le marché de l'emploi. Communication présentée au Colloque International sur la performance des organisations, ENCG El Jadida - Maroc, 2016

[4] Khan, M. I., Mourad, S. M., \&Zahid, W. M., Developing and qualifying Civil Engineering Programs for ABET accreditation. Journal of King Saud University-Engineering Sciences, 28(1), 1-11, 2016

[5] Duarte, M., \& Costa, A., Meaning and benefits of the EUR-ACE label: Portuguese higher education institutions. In Interactive Collaborative Learning (ICL), 2015 International Conference on (pp. 1013-1017). IEEE, 2015

[6] Engineers Australia professional site, URL: http://www.engineersaustralia.org.au/aboutus/program-accreditation\#AP2

[7] The EUR-ACE (EURopeanACcredited Engineer) (date de consultation 20 Avril 2016). « EUR-ACE® Framework Standards and Guidelines (Edition 31st March 2015) ». [PDF].URL :http://enaee.eu/wp-content/uploads/2015/04/EUR-ACE-Framework-Standards-andGuidelines-Mar-2015.pdf.

[8] ABEEK (Accreditation Board for Engineering Education of Korea), URL: http://www.abeek.or.kr/abeek/history .

[9] Jin, Y., Ahn, K., \& Choi, B.,An use of course-embedded assessment for assessing program outcomes. In Proceedings of the World Congress on Engineering and Computer Science (Vol. 1), 2010

[10] Duarte, M., Leite, C., \&Mouraz, A.,The effect of curricular activities on learner autonomy: the perspective of undergraduate mechanical engineering students. European Journal of Engineering Education, 41(1), 91-104, 2016

[11] Nair, C. S., Patil, A., \&Mertova, P., Re-engineering graduate skills-a case study.European Journal of Engineering Education, 34(2), 131-139, 2009

[12] Engineering Accreditation Commission( Effective for Reviews During the 2015-2016 Accreditation Cycle), Accreditation Board for Engineering and Technology. Criteria for Accrediting Engineering Programs, 2014

[13] Patil, A., \&Codner, G., Accreditation of engineering education: review, observations and proposal for global accreditation. European journal of engineering education, 32(6), 639-651, 2007

[14] ABEEK, KEC2005 engineering criteria documentation, ABEEK-2006-AB-021, 2006

[15] Engineers Australia, stage 1 competency standard for professional engineer (Version 3: 21 June 2013)URL :http://www.engineersaustralia.org.au/sites/default/files/shado/Education/Program\%20Accred itation/150903_stage_1_pe_2013_approved.pdf

[16] Edward F. Crawley, Johan Malmqvist, SörenÖstlund, Doris R. Brodeur and Kristina Edström, Rethinking engineering education: the CDIO approach (second edition): Springer International Publishing Switzerland, 2014 
[17] Référentiel générique d'acquis de l'apprentissage CDIO adapté à Télécom BretagneTraduction Télécom Bretagne "CDIO Syllabus v2.0, june 2011", 20/09/2013.

[18] BaiJianfeng*, Lei Hu, Yanfen Li, Zhen Tian, LiliXie, Lijun Wang, Mingyuan Zhou, Jie Guan, HuaqingXie, The progress of CDIO engineering education reform in several China universities: A review, ScienceDirect, 2013

[19] O.M. Zamyatina*, M.G. Minin, D.S. Denchuk, V.O. Sadchenko , Analysis of engineering invention competencies in standards and programmes of engineering universities, Sciencedirect, 2015

[20] LE BOTERF, G., Repenser la compétence pour dépasser les idées reçues: 15 propositions (éd. 2). Paris, Organisation, 2008

[21] Brochure du projet Tempus P@lmes cadre national marocain commun pour la certification des compétences transversales (2012/2015), site officiel: http://epalmes.uca.ma/

[22] Vijayalakshmi, V., Soft Skills-The Need of the Hour for Professional Competence: A Review on Interpersonal Skills and Intrapersonal Skills Theories, International Journal of Applied Engineering Research, 11(4), 2859-2864, 2016

[23] Chou, W., Fast-tracking Your Career: Soft Skills for Engineering and IT Professionals. John Wiley \& Sons, Copyright (C) 2013 by the Institute of Electrical and Electronics Engineers (IEEE), 2013

[24] Holland, D., \& JIM CROMPTON, M. S., The Future Belongs to the Digital Engineer. Xlibris Corporation, 2013

[25] Cahier des Normes pédagogiques nationales du cycle ingénieur, Maroc, 2014http://www.umi.ac.ma/wp-content/uploads/2012/03/CNPN-Cycle-Ing\%C3\%A9nieur_2014.pdf

[26] Ecoles d'ingénieurs au Maroc, Dossiers d'accréditation des filières d'ingénierie, 20142015

[27]Casablanca Smart city cluster, e-Madina, http://www.e-madina.org/ 